\title{
ANALISIS PENERIMAAN RETRIBUSI IZIN MENDIRIKAN BANGUNAN DALAM PENGHIMPUNAN RETRIBUSI DAERAH KABUPATEN SAROLANGUN
}

\author{
Dewi Susanti \\ Prodi Keuangan Daerah FEB Universtias Jambi \\ dewisusanti20@gmail.com
}

\begin{abstract}
Abstrak
Tujuan dari penelitian ini untuk mengetahui dan menganalisis Efektivitas Penerimaan Retribusi Izin Mendirikan Bangunan di Kabupaten Sarolangun dan kontribusi Retribusi Izin Mendirikan Bangunan Terhadap Total Retribusi Daerah Kabupaten Sarolangun Tahun 2006-2013. Metode yang digunakan untuk menjawab permasalahan dalam penelitian ini adalah data deskriptif kuantitatif. Hasil analisis dari pnelitian ini menunjukan bahwa: efektivitas penerimaan retribusi izin mendirikan bangunan kabupaten sarolangun tahun 2006-2013 sebesar 99,7\%, ini artinya Kabupaten Sarolangun untuk pendapatan Izin Mendirikan Bangunan masih belum sesuai dengan bangunan yang ada di kabupaten sarolangun dan perlu untuk di tingkatkan kembali. Kontribusi Retribusi Izin Mendirikan Bangunan terhadap total Retribusi Daerah Kabupaten Sarolangun sebesar 23,14 \% yang artinya masih kecil pendapatan yang harus di serahkan ke daerah, berarti belum banyak masyarakat yang berkontribusi melalui izin mendirikan bangunan.
\end{abstract}

Kata Kunci : penerimaan, retribusi, izin mendirikan bangunan

\begin{abstract}
The purpose of this study was to determine and analyze the Effectiveness of the Receipt of Building Permits in Sarolangun Regency and the contribution of Building Permits to the Total Levies of the Sarolangun Regency in 2006-2013. The method used to answer the problem in this study is quantitative descriptive data. The results of the analysis of this study show that: the effectiveness of receiving levies for building permits in Sarolangun regency in 2006-2013 was 99.7\%, this means that Sarolangun Regency for Building Permit income is still not in accordance with existing buildings in Sarolangun District and needs to be improved back. Contribution of Building Permit Levies to Sarolangun District Levies totals 23.14\%, which means that there is still little revenue to be submitted to the regions, meaning that not many people have contributed through building permits.
\end{abstract}

Keywords: revenue, retribution, building permit

\section{PENDAHULUAN}

Pembangunan pada hakekatnya merupakan suatu proses perubahan yang terus menerus pada kemajuan dan peningkatan kemakmuran rakyat yang berdasarkan pancasila dan Undang -Undang Dasar 1945. Pembangunan merupakan upaya pemanfaatan segala potensi yang ada di masing - masing daerah, oleh karna itu pembangunan lebih diarahkan kedaerah daerah, sehingga pelaksanaan pembangunan tersebut diserahkan langsung kepada tiap tiap daerah untuk mengatur rumah tangga nya sendiri. Untuk itu pada tahun 2000 diberlakukannya otonomi daerah yang di tandai 
dengan dikeluarkannya Undang- undang no 22 tahun 1999 yang di perbarui dengan undang- undang nomor 32 tahun 2004 tentang pemerintah daerah

Pelaksanaan undang-undang nomor 32 tahun 2004 tentang pemerintah daerah dan undang-undang nomor 33 tahun 2004 tentang perimbangan keuangan antara pemerintah pusat dan pemerintah daerah maka menjadi tanggung jawab bagi setiap daerah untuk memenuhi kebutuhan daerahnya masing -masing. Dengan dilaksanakannya otonomi daerah dengan perinsip yang luas, nyata dan bertanggung jawab, di harapkan pemerintah daerah mampu mengatur dan mengurus daerah nya sendiri, dapat lebih mampu menggali sumber- sumber keuangan khususnya untuk memenuhi kebutuhan pembiayaan pemerintahan dan pembangunan di daerah nya melalui pendapatan asli daerah sesuai dengan potensi yang dimiliki, akan semangkin pembangunan dan mengembangkan potensi yang ada dimasing masing daerah dan mampu untuk membiayai penyelenggaraan pemerintahan daerah.

Daerah yang mampu menghasilkan pendapat asli daerah yang besar akan mampu untuk melakukan kegiatan pembangunannya, dengan kemampuan daerah yang memiliki penerimaan pendapatan asli daerah yang besar akan lebih cepat maju dan berkembang dibandingkan daerah dengan pendapatan asli daerah yang kecil.semakin besar pembangunan maka semakin besar pula biaya yang dikeluarkan.untuk itu peningkatan sumber pendapatan daerah di pandang sebagai salah satu cara yang efektif untuk mencapai kesejahteraan masyarakat. Berdasarkan peraturan pemerintah nomor 66 tahun 2001 tentang retribusi daerah, retribusi daerah merupakan salah satu jenis retribusi yang mampu memberikan sumbangan cukup besar terhadap pendapat retribusi daerah hingga mampu meningkatkan pendapat asli daerah (PAD). Salah satu pungutan retribusi daerah yang mampu meningkatkan Pendapatan Asli Daerah Kabupaten Sarolangun adalah Retribusi Izin Mendirikan Bangunan (IMB).

Agar pembangunan yang terjadi di daerah dapat berjalan sesuai dengan yang diharapkan, maka pemerintah menerapkan perizinan atas pembangunan yang akan dilaksanakan. Dalam hal ini setiap masyarakat yang akan mendirikan bangunan baik yang berupa rumah, toko, gedung dan sebagainya maka harus melalui izin terlebih dahulu yaitu izin mendirikan bangunan (IMB). Selain untuk pengaturan pembangunan daerah diKabupaten Sarolangun, dalam hal ini juga terkait dengan adanya upaya peningkatan pendapatan daerah dalam rangka otonomi daerah Jadi, dalam rangka desentralisasi maka setiap daerah diberi kewenangan untuk mengelola dan mengatur daerahnya sendiri, terutama dalam rangka peningkatan pendapatan Asli Daerah (PAD), yang salah satunya pemerintah daerah juga berupaya meningkatkan pendapatan melalui penyelenggaraan pungutan retribusi izin mendirikan bangunan.

Peraturan daerah Kabupaten Sarolangun nomor 14 tahun 2012 tentang bangunan dan Retribusi Izin Mendirikan bangunan yang dipandang sudah tidak sesuai dengan kondisi sekarang.pemerintah kabupaten sarolangun dalam pembiayaan dan pembangunan terus berusaha untuk meningkatkan Pendapatan Asli Daerah (PAD) melalui penerimaan Retribusi Izin Mendirikan bangunan yang merupakan sebagai salah satu sumber pendapatan dari Pendapatan Asli Daerah. Retribusi Izin Mendirikan bangunan di Kabupaten Sarolangun. Pada tahun 2009 realisasi penerimaan retribusi izin mendirikan bangunan sebesar Rp 55.858975 atau 55\% dan tahun 2010 realisasi penerimaan retribusi izin mendirikan bangunan sebesar Rp 31.908000 atau $31 \%$ dan tahun 2011 penerimaan retribusi izin mendirikan bangunan sebesarRp 77.539000 atau $258 \%$ dan pada tahun 2012 penerimaan retribusi izin mendirikan bangunan sebesar Rp 40.682000 atau $54 \%$ pada tahun 2013 penerimaan retribusi Izin Mendirikan 
Bangunan sebesar Rp 37.881000 .atau $126 \%$ di Kabupaten Sarolangun Sangat Efektif karena penerimaan realisasinya lebih kecil,dan selalu menurun. Berdasarkan latar belakang diatas, untuk menganalisis penerimaan Retribusi Izin Mendirikan Bangunan Kabupaten Sarolangun maka penulis bermaksud untuk melakukan penelitian dengan judul Analisis Penerimaan Retribusi Izin Mendirikan Bangunan dalam Penghimpunan Retribusi Daerah Kabupaten Sarolangun. Permasalahan dalam penelitian ini adalah bagaimana Efektivitas Penerimaan Retribusi Izin Mendirikan Bangunan dan seberapa Besar Kontribusi Penerimaan Retribusi Izin Mendirikan Bangunan Terhadap Total Retribusi Daerah Kabupaten Sarolangun.Tahun 2006-2013?

\section{METODE PENELITIAN}

\section{Jenis dan Sumber Data}

Jenis data yang digunakan dalam penelitian ini adalah data sekunder periode 2006-2013 “ Data sekunder adalah data yang berasal dari pihak ke dua atau data yang sudah pernah diolah sebelumnya.Adapun data yang digunakan dalam penelitian ini adalah :

1. Data Pendapatan Asli Daerah Kabupaten Sarolangun

2. Data Retribusi Daerah beserta komponen

3. Data Retribusi Izin Mendirikan Bangunan.

Ada pun sumber data yang di gunakan dalam penelitian ini berasal dari:

1. Dinas Pendapatan Pengelolaan Keuangan dan Aset Daerah (DPPKAD) Kabupaten Sarolangun

2. Badan Pelayanan Perizinan Terpandu Satu Pintu( BPPTSP) Kabupaten Sarolangun

3. Badan Pusat Statistik (BPS) Kabupaten Sarolangun

\section{Metode Analisis Deskriptif}

Untuk menjawab tujuan pertama yaitu mengetahui Efektivitas penerimaan retribusi Izin Mendirikan Bangunan. di gunakan rumus sebagai berikut (Halim,2007).

EPRIMB $=\frac{\text { RPRIMB }}{\text { TPRIMB }} \times 100 \%$
Keterangan
EPRIMB = Efektivitas Penerimaan Retribusi Izin Mendirikan Bangunan
RPRIMB = Realisasi Penerimaan Retribusi Izin Mendirikan Bangunan
TPRIMB $=$ Target Penerimaan Retribusi Izin Mendirikan Bangunan

\section{Kriteria}
a. Diatas $100 \%$ Sangat Efektif
b. $90 \%-100 \%$ Efektif
c. $80 \%-90 \%$ Cukup Efektisf
d. $60 \%-80 \%$ Kurang Efektif

Untuk menjawab tujuan kedua yaitu seberapa besar kontribusi penerimaan retribusi Izin mendirikan bangunan terhadap total retribusi daerah. di gunakan rumus : 


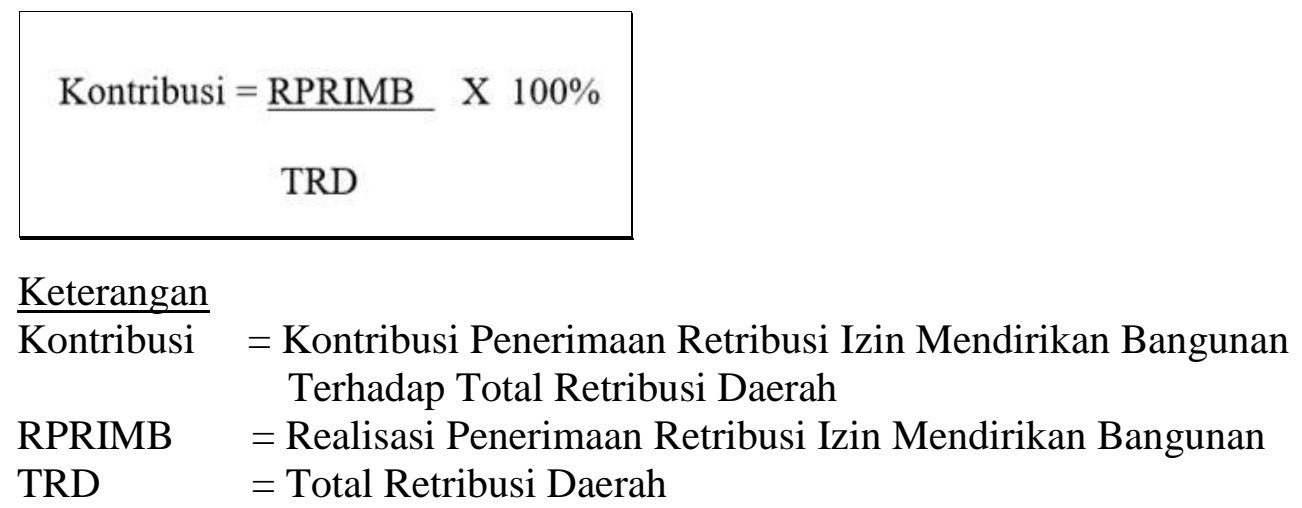

\section{HASIL DAN PEMBAHASAN}

\section{Analisis Efektivitas Penerimaan Retribusi Izin Mendirikan Bangunan}

Sebagai komponen penerimaan Pendapatan Asli Daerah(PAD) maka retribusi izin mendirikan bangunan harus menerus di upayakan agar terjadi peningkatan secara bersinambungan setiap tahun. Penerimaan retribusi Izin mendirikan bangunan daerah yang terus meningkat pada daerah di harapkan akan mendukung kemampuan pembiayan daerah. Selain di harapkan peningkatan realisasi penerimaan izin mendirikan bangunan dari tahun ke tahun, yang paling penting untuk di perhatikan adalah efektivitas penerimaan retribusi izin mendirikan bangunan itu sendiri.Untuk lebih jelas lagi bisa di lihat pada tabel 5.1. berikut:

Tabel 1. Efektivitas Retribusi Izin Mendirikan Bangunan Kabupaten Sarolangun Tahun 2006 - 2013

\begin{tabular}{|c|c|c|c|c|}
\hline Tahun & $\begin{array}{c}\text { Target } \\
\text { (Rp) }\end{array}$ & $\begin{array}{l}\text { Realisasi } \\
\text { (Rp) }\end{array}$ & $\begin{array}{c}\text { Efektivitas } \\
(\%)\end{array}$ & Kriteria \\
\hline 2006 & 60.000000 & 70.326 .390 & 117 & Sangat Efektif \\
\hline 2007 & 65.000000 & 68.062 .780 & 104 & Sangat Efektif \\
\hline 2008 & 150.000000 & 79.154 .827 & 52 & Kurang efektif \\
\hline 2009 & 100.000000 & 55.858 .975 & 55 & kurang efektif \\
\hline 2010 & 100.000000 & 31.908 .000 & 31 & Kurang efektif \\
\hline 2011 & 30.000000 & 77.539 .000 & 259 & Sangat fektif \\
\hline 2012 & 75.000000 & 40.682 .000 & 54 & kurang efektif \\
\hline 2013 & 30.000000 & 37.881 .000 & 126 & Sangat efektif \\
\hline \multicolumn{3}{|c|}{ Rata - rata } & 99,7 & Efektif \\
\hline
\end{tabular}

Sumber : DPPKD DAN BPPTSP Kabupaten Sarolangun(data diolah)

Berdasarkan tabel 1 dapat dilihat bahwa selama tahun 2006- 2013 menunjukkan kecenderungan berfluktuasi,efektivitas Izin Mendirikan Bangunan tertiggi terjadi pada tahun 2011 sebesar 259\% artinya sangat efektif,dan terendah terjadi pada tahun 2010 sebesar 31\% artinya kurang efektif,sedangkan rata - rata dari tahun 2006- 2013 di Kabupaten Sarolanun realisasi penerimaan retribusi izin mendirikan bangunan sebesar 99,7 \% dalam satuan persentase ini artinya Efektif.

Apabila dilihat dari masing-masing tahun, pada tahun 2006 target penerimaan retribusi IMB sebesar Rp 60,000 000 dan realisasinya sebesar Rp 70,326 390 atau 117 $\%$ artinya sangat efektif. Pada tahun 2007 target penerimaan retribusi IMB sebesar Rp 65,0000 000 dan realisasinya sebesar Rp 68,062 780 atau 104\% artinya sangat efektif. 
Sementara pada tahun 2008 target penerimaan retribusi IMB sebesar Rp 150,000 000 dan realisasinya sebesar Rp 79,154 827 atau 55 ini artinya kurang efektif. Pada tahun 2009 target penerimaan retribusi IMB sebesar Rp 100,000 000 dan realisasinya sangat jauh menurun sebesar Rp 55,858 975 ini artinya kurang efektif. Dan pada tahun 2010 target penerimaan retribusi IMB sebesar Rp 100,000 000 dan realisasnya sebesar Rp 31,908000 atau 31\% ini artinya kurang efektif.Sudah tiga tahun terakhir ini sudah terlihat bahwa penerimaan retribusi izin mendirikan bangun tidak mencukupi target yang sudah di tentukan. Pada tahun 2011 meningkat kembali penerimanaan retribusi IMB targetnya sebesar Rp 30,000 000 dan realisasinya sebesar Rp 77,539 000 atau $259 \%$ artinya sangat efektif.pada tahun 2012 target penerimaan retribusi IMB sebesar $\mathrm{Rp} 75,000000$ dan realisasinya sebesar $\mathrm{Rp}$ 40,682 000 atau 54\% ini artinya kurang efektif. Pada tahun 2013 target penerimaan retribusi Izin Mendirikan Bangunan sebesar Rp 30,000 000 dan realisasinya sebesar Rp 37,881 000 atau 126\% artinya sangat efektif. Dengan kurang optimalnya dalam pemungutan retribusi Izin Mendirikan Bangunan.

Untuk melihat lebih jelas efektivitas target dan realisai retribusi izin mendirikan bangunan di Kabupaten Sarolangun tahun 2006-2013 dapat dilihat pada grafik sebagai berikut:

Grafik 1: Target dan realisasi retribusi izin mendirikan bangunan

Kabupaten Sarolangun

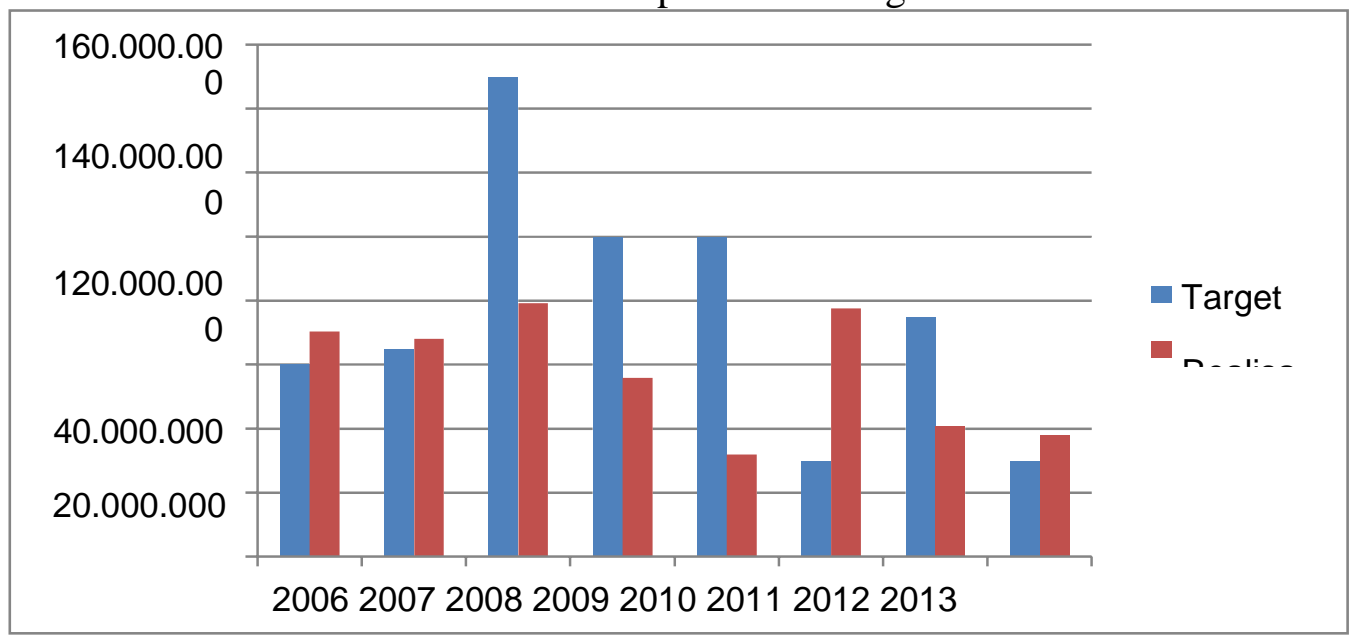

Untuk mengetahui lebih jelas Tingkat Efektivitas Retribusi izin Mendirikan Bangunan Kabupaten Sarolangun Tahun 2006-2013 dapat di lihat pada grafik berikut : 
Grafik 2 : Efektivitas Retribusi Izin Mendirikan Bangunan

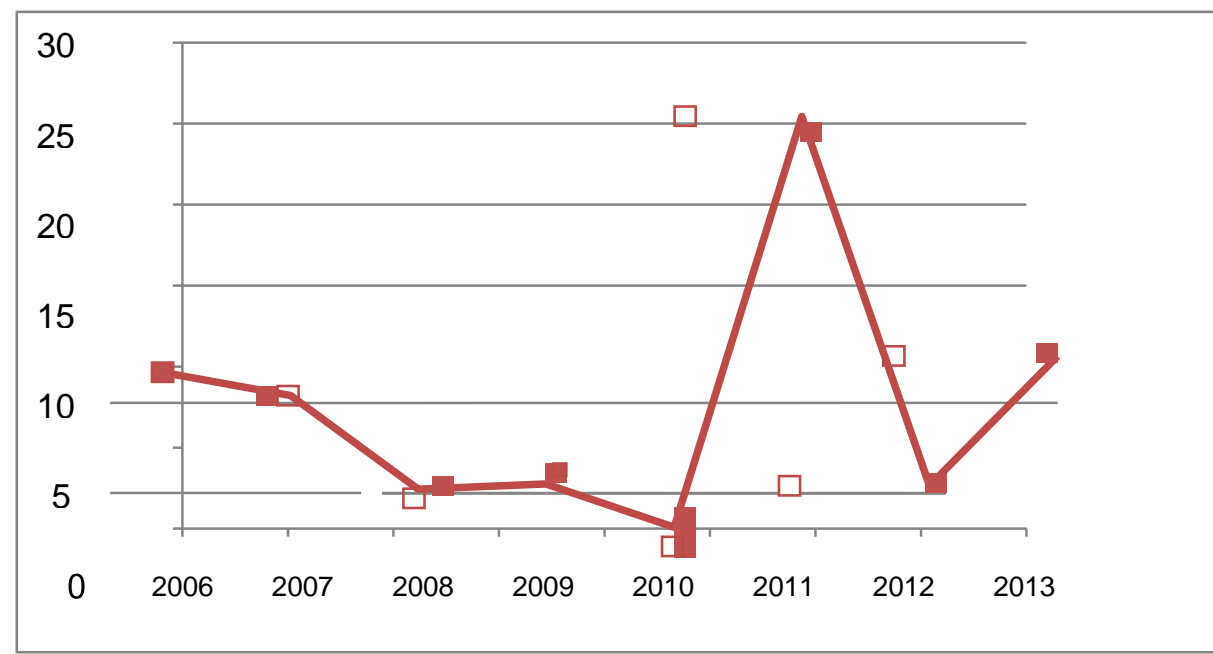

\section{Kontribusi Retribusi Izin Mendirikan Bangunan Pada Total Retribusi Daerah}

Retribusi daerah sebagai salah satu sumber Pendapatan Asli Daerah mempunyai peranan penting dalam memberikan sumbangan terhadap peningkatan Pendapatan Daerah semangkin banyak berkontribusi ke daerah merupakan salah satu pos penerimaan penyumbangan terbesar sebagai komponen pembentukan pendapatan asli daerah.maka retribusi daerah harus terus menerus di upayakan agar jadi peningkatan secara berkesinambungan setiap tahun, hal ini tentu sejalan dengan perkembangan perekonomi yang ada diKabupaten Sarolangun khususnya perkembangan pembangunan.Kontribusi retribusi izin mendirikan bangunan terhadap total retribusi daerah dapat di lihat dari tabel 5.2 sebagai berikut :

Tabel 2 : Kontribusi Retribusi Izin Mendirikan Bangunan Terhadap Total Retribusi Daerah Kabupaten Sarolangun

\begin{tabular}{|c|c|c|c|}
\hline Tahun & $\begin{array}{c}\text { Realisasi Ret.IMB } \\
\text { (RP) }\end{array}$ & $\begin{array}{c}\text { Total Ret,Daerah } \\
(\mathbf{R p )}\end{array}$ & $\begin{array}{c}\text { Kontribusi } \\
\mathbf{\%}\end{array}$ \\
\hline 2006 & 70.326390 & 1.911013699 & 36.8 \\
\hline 2007 & 68.062780 & 1.146583546 & 59.3 \\
\hline 2008 & 79.154827 & 2.037565381 & 38,8 \\
\hline 2009 & 55.858975 & 4.741219580 & 11,7 \\
\hline 2010 & 31.908000 & 6.057375052 & 5.2 \\
\hline 2011 & 77.539000 & 4.685479495 & 16.5 \\
\hline 2012 & 40.682000 & 3.715141855 & 10.9 \\
\hline 2013 & 37.881000 & 6.692764958 & 5.6 \\
\hline \multicolumn{4}{|c|}{ Rata -rata } \\
\hline
\end{tabular}

Dari hasil perhitungan pada tabel 2 kontribusi retribusi izin mendirikan bangunan terhadap total retribusi daerah di Kabupaten Sarolangun cenderunga berfluktuasi selama periode tahun 2006 - 2013 Kontribusi Retribusi Izin Mendirikan Bangunan Terhadap Total Retribusi Daerah yang paling tertinggi terjadi pada tahun 2007 sebesar 59,3 dan yang terendah terjadi pada tahun 2010 sebesar 5,2\% sedangkan rata - rata 
pencapaian kontribusi retribusi izin mendirikan bangunan terhadap total retribusi daerah sebesar 23,14\%.pertahun. Apabila kalau dilihat dari Masing-masing tahun. Pada tahun 2006 realisasi retribusi izin mendirikan bangunan sebesar Rp 70,326 390 dan total retribusi daerah sebesar Rp 1,911 013699 atau 36,8 \%. Pada tahun 2007 realisasi retribusi izin mendirikan bangunan sebesar Rp 68,062 780 dan total retribusi daerah sebesar Rp 1,146 583546 atau 59,3\% pada tahun 2008 realisasi retribusi izin mendirikan bangunan sebesar Rp 79,154 827 dan total retribusi daerah sebesar Rp 2,037 565381 atau 38,8 \% pada tahun 2009 realisasi retribusi izin mendirikan bangunan sebesar Rp 55,858 975 dan total retribusi daerah sebesar Rp 4,741 219580 atau 11,7 \% pada tahun 2010 realisasi retribusi izin mendirikan bangunan sebesar Rp 31,908 000 dan total retribusi daerah sebesar Rp 6.057375052 atau $5.2 \%$ pada tahun 2011 realisasi retribusi izin mendirikan bangunan sebesar Rp 77,539 000 dan total retribusinya sebesar Rp 4.685479495 atau 16,5\% pada tahun 2012 realisasi retribusi izin mendirikan bangunan sebesar Rp 40,682 000 dan total retribusi daerah sebesar Rp 3,715141855 atau $10,9 \%$ pada tahun 2013 realisasi retribusi izin mendirikan bangunan sebesar Rp 37,881000 dan total retribusi daerah sebesar Rp 6,692 764958 atau 5,6\%. Artinya retribusi izin mendirikan bangunan terhadap total retribusi daerah masi kecil untuk Kabupaten Sarolangun.

Untuk melihat lebih jelas lagi realisasi retribusi izin mendirikan bangunan di Kabupaten Sarolangun tahun 2006 - 2013 dapat di lihat pada grafik sebagai berikut:

Grafik 3: Retribusi Izin Mendirikan Bangunan Terhadap Total Retribusi Daerah Kabupaten Sarolangun

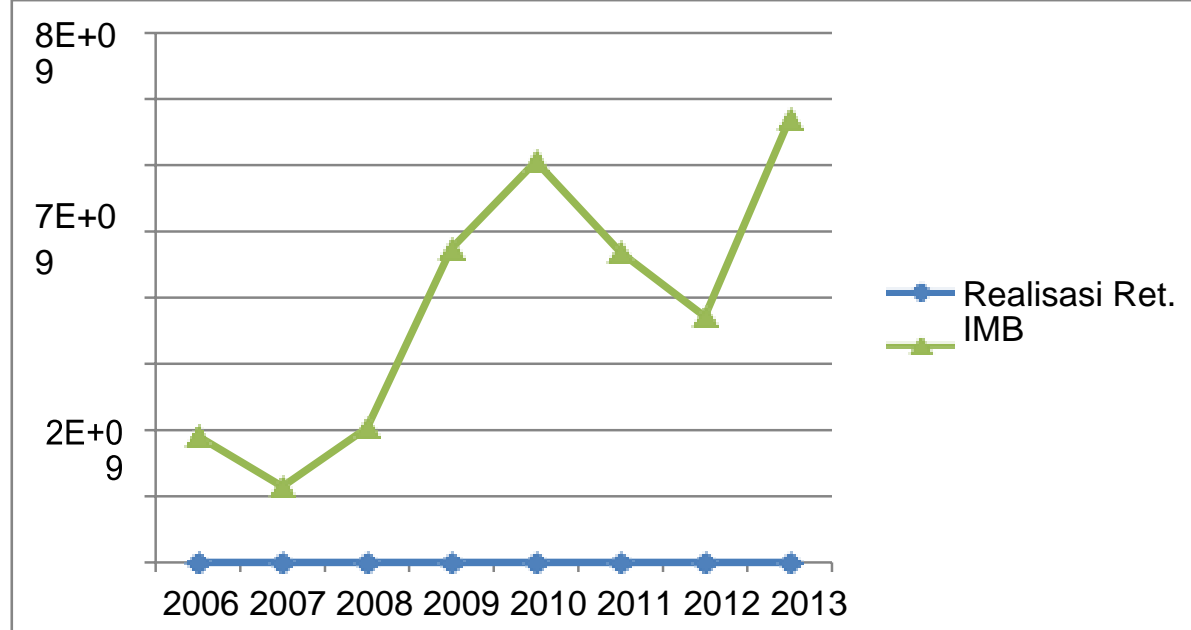

Untuk mengetahui lebih jelas tingkat kontribusi retribusi izin mendirikan bangunan terhadaptotal retribusi daerah dapat di lihat grafik berikut : 
Grafik 4 : Kontribusi Retribusi Izin Mendirikan Bangunan TerhapTotaLRetribusi

Daerah kabupaten sarolangun

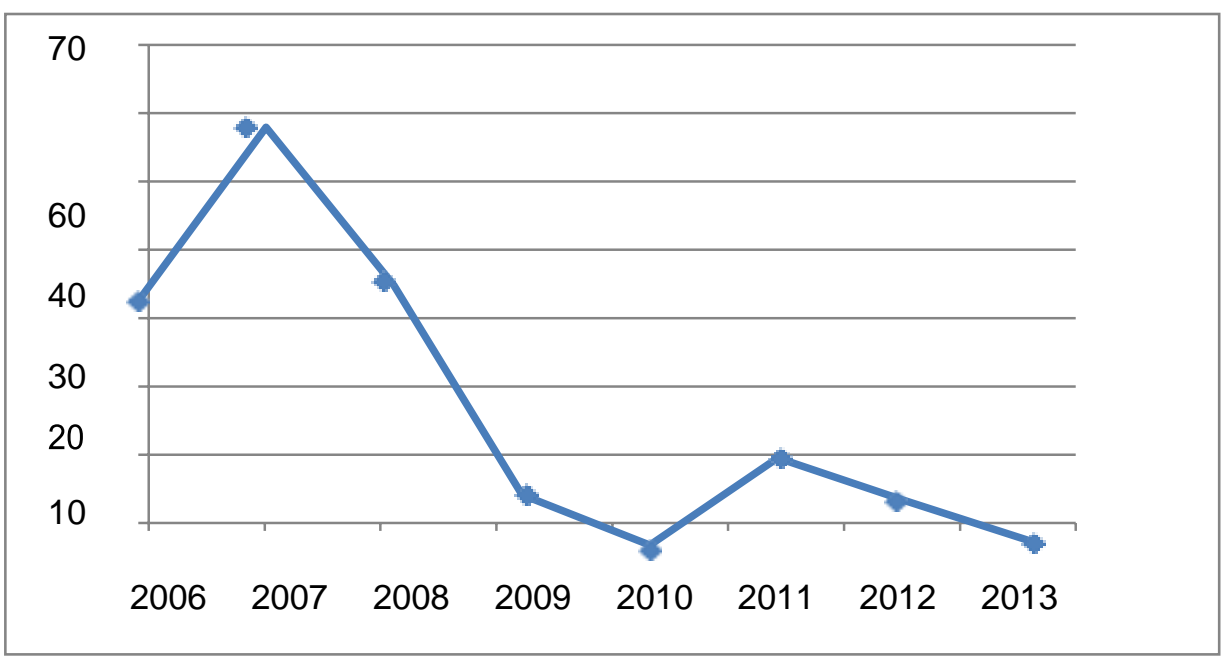

\section{SIMPULAN DAN SARAN}

Efektivitas penerimaan retribusi izin mendirikan banguanan di Kabupaten Sarolangun tertinggi terjadi pada tahun 2011 sebesar 259\% pada tahun ini pembangunan di kabupaten sarolangun sudah mulai berkembang pembangunan dan juga masyarakat sudah mulai mengetahui untuk mengurus surat izin atas bangunan yang telah didirikan. Dan yang terendah terjadi pada tahun 2010 sebesar $31 \%$ dikarenakan tahun ini belum banyak masyarakat mengurus izin.Sedangkan rata - rata Efektivitas Izin Mendirikan Bangunan selama periode 2006 - 2013 sebesar 99,7 \% pertahun.

Kontribusi Retribusi Izin Mendirikan Bangunan terhadap total Retribusi Daerah Kabupaten Sarolangun tertinggi terjadi pada tahun 2007 sebesar 59,3 \% dan yang terendah terjadi pada tahun 2010 sebesar 5,2 \% sedangkan rata - rata kontribusi retribusi izin mendirikan bangunan terhadap total retribusi daerah selama periode 2006 - 2013 sebesar 23,14\% pertahun

Efektivitas retribusi izin mendirikan bangunan masih dalam kriteria efektif, jadi untuk instansi yang memungut retribusi perizinan agar lebih optimal lagi memberikan sosialisasi kepada masyarakat dalam mengurus perizinan, jika retribusi perizinan meningkat lagi maka pendapatan asli daerah akan lebih baik, dan perkembangan pembangunan akan lebih meningkat.

Kontribusi retribusi izin mendirikan bangunan terhadapa total retribusi daerah masih alam angka kecil, jadi untuk dinas yang memungut retribusi daerah agar lebih giat lagi untuk sosialisasi kepada masyarakat agar mengurus izin, supaya retribusi daerah lebih meningkat dari sebelumnya.

\section{DAFTAR PUSTAKA}

Anggawen F. (2006). Disparitas Kontribusi Pajak dan Retribusi Daerah Dalam Kaitan dengan Perkembangan Wilayah di Kabupaten Kota Bogor.Tesis Instutusi Pertanian Bogor.

Anonim (2004). Undang -Undang Nomor 32 Tahun 2004 Tentang Pemerintah Daerah. 
Anonim (2001) Peraturan Pemerintah Nomor 66 Tahun 2001, Retribusi Daerah Anonim, Undang- Undang Nomor 28 Tahun 2009, Tentang Wewenangan pemungutan pajak daerah dan retribusi daerah.

Anonim Undang-Undang Nomor 7 Tahun 2013 Tentang Perizinan Kabupaten Sarolangun Badan Pelayanan Perizinan Terpandu Satu Pintu(BPPTSP) Kabupaten SarolangunBadan Pusat Statistik (BPS) Kabupaten Sarolangun.

Darise Nurlan. (2009). Pengelolaan Keuangan Pada Satuan Kerja Perangkat Daerah (SKPD) dan BLU.Edisi Kedua .Jakarta:PT.Indek

Dinas Pendapatan Pengelolaan Keuangan dan Aset Daerah (DPPKAD) Kabupaten Sarolangun.

Haryadi, Dedy (2003). Kontribusi Retribusi Pasar Terhadap Peningkatan PAD dalam Melaksanakan Otonomi Daerah Kota Bengkulu.Skripsi Fisip UMY, Yogyakarta.

Halim, A. (2004) Bungo Rampai Manajemen Keuangan Daerah Edisi Revisi,UPP AMP YKPN,Yokyakarta

Kaho, Josef Riwu (2007). Prospek Otonomi Daeah di Negara Republik Indonesia Jakarta PT Raja Grafindo Persada.

Mardiasmo (2005). Perpajakan Edisi Revisi,Yokyakarta

Prakoso, Kesit Bambang (2003). Pajak dan Retribusi Daerah Ull Press, Yokyakarta

Resmi, Siti (2013). Perpajakan dan Teori Kasus,Selemba Empat di Jakarta Selatan

Siahaan, Marihot Pahala. (2005). Pajak Daerah dan Kontribusi Daerah.Raja Grafindo Persaja,Jakarta.

Supardi (2006). Kontribusi Pendapatan Retribusi Daerah Terhadap Pendapatan Asli Daerah (PAD) di Kabupaten Bantul periode 1996/1997-2005.STIE Nusa Megarkencana,Yogyakarta

Suparmoko .M 2008 Keuangan Negara Dalam Teori dan Praktek BPFE ,YOGYAKARTA

Yani, A. (2008). Hubungan Keuangan antara Pemerintah Pusat dan Daerah di Indonesia. Edisi Revisi, Jakarta:PT Raja Grafindo Persada. 